\title{
Evaluation of Different Land Preparation Techniques for Preparing Medium Textured Soil in Rice Production under Agro-Ecological Conditions of Sheikhupura-Pakistan
}

\author{
Usman Hassan $^{1, a}$, Muhammad Shahbaz ${ }^{1, b}$, Muhammad Saleem Kashif ${ }^{1, c}$, Liaqat Ali ${ }^{1, d}$, \\ Muhammad Tariq Chaudhary ${ }^{1, \mathrm{e}}$, Wardah Qamar ${ }^{1, \mathrm{f}}$ \\ ${ }^{I}$ Punjab Agriculture Department, Government of Punjab, Pakistan \\ *Corresponding author
}

A R T I C L E I N F O

Research Article

Received : 20/03/2021 Accepted : 20/08/2021

Keywords: Puddling

Dry land preparation Disc harrow Transplanting MB Plough

\section{A B S T R A C T}

Tillage is an important factor affecting different soil properties and crop yields. Tillage relates to applying forces to soil using different implements for preparation of a proper seed bed. For rice crop, land preparation is a rigorous and time consuming operation that needs special attention for preparing a puddled soil condition to transplant the weak and tender rice seedlings. A field experiment was established under agro-ecological conditions of Sheikhupura to evaluate different land preparation techniques during fall in 2017 and 2018 years. The experiment was performed at Adaptive Research Farm Sheikhupura. It was laid out in randomized complete block design (RCBD) with four different land preparation techniques including $\mathrm{T}_{1}=$ Cultivator $(4$ times $)+$ Planking (2 times) (Farmer's Practice), T2=MB plough (1 time) + Disc Harrow (1 time) + Planking ( 2 Times $), \mathrm{T}_{3}=\mathrm{MB}$ plough $(1$ time $)+$ Cultivator $(2$ times $)+$ Planking $(2$ Times $)$ and $\mathrm{T}_{4}=$ Rotavator (1 time) + Disc Harrow (1 time) + Planking (2 Times), each treatment replicated thrice during both the years. All the other agronomic and crop husbandry operations were kept uniform throughout the growing season every year. The results revealed that preparing land with MB plough (1 time), Disc Harrow (1 time) and Planking (2 times) is the best land preparation method can increase the paddy yield 13.5-17.5\% as compared to the traditional method practised by the farmers. Moreover, highest plant height $(134.00 \mathrm{~cm}$ and $132.00 \mathrm{~cm})$, number of tillers $\left(224\right.$ and $\left.220 \mathrm{~m}^{-2}\right)$, number of grains per spike (130 and 116) and 1000-grain weight (23.0 and $22.0 \mathrm{~g}$ ) respectively during Kharif-18 and Kharif-19 was also recorded in the same treatment. So, preparation of land for paddy in agroecological conditions of Sheikhupura using MB plough (1 time), Disc Harrow (1 time) and Planking (2 times) can significantly enhance the paddy yield. a usmanhassan614@gmail.com kashif1637@gmail.com edrtariq273rb@gmail.com
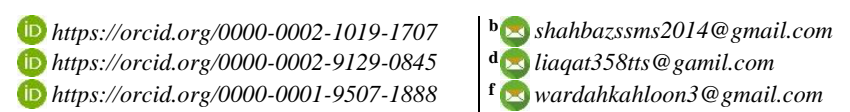

(iD https://orcid.org/0000-0002-6447-1288 (iD) htps://orcid.org/0000-0002-9315-3094 (iD) https://orcid.org/0000-0001-5019-2731

(c) $($ ) (9) This work is licensed under Creative Commons Attribution 4.0 International License

\section{Introduction}

Rice is considered among the most important cereals of the world. About $33 \%$ world population use rice as staple food making it an important cereal crop of the world (Nasiri et al., 2008). In Pakistan, it is grown on an area of about $10 \%$ of total cultivated area.

Rice is an important cash crop in Pakistan. Rice grains fulfil the $60 \%$ food needs of people of Pakistan. Pakistan is a major rice exporter with an annual export of approximately 2.0 million ton of basmati rice (Rehman et al., 2015). Despite the multi-dimensional efforts from all stake holders concerned with rice, the paddy yield is still very low in Pakistan. There are several factors of low rice yield such as low plant density, poor seed quality, and deficient moisture in seed bed, attack of insect pests, different diseases, climate change, improper fertilizer application, improper irrigation management and proper seed bed preparation for rice crop. Among all these factors land preparation is an important factor for rice cultivation. Seed bed preparation is the factor that may cause low productivity of rice. Improper seed bed may cause salinity, waterlogging, moisture and loss of nutrients. For uniform land preparation, it is necessary to use proper tillage combinations. Tillage relates to applying forces to soil with the help of different implements for preparation of proper seed bed. Tillage control weeds, incorporate residues in the soil, loose the soil and enhance the aeration of soil hence change occurs in different physiochemical properties of soil which ultimately effect the crop development and yield of a crop (Shahidur-Rehman et al., 2004). Tillage is an important factor that influences the soil physical properties and yield of crop. Selection of appropriate tillage practices is crucial for crop growth otherwise improper practices 
may cause the adverse effect on crop productivity (Md. Khairul Alam et al., 2014). Tillage is the primary part of any crop production system and has direct effect on crop yield and crop stand (Hobbs, 2001) and the changes in the soil layer to provide a favourable environment for crop growth (Culpin, 1981). Changes in soil properties due to tillage depends upon several factors including moisture contents in soil at the time of tillage, tillage depth, equipment used and climatic conditions (Chang and Lindwall, 1990). Increasing the plough depth and time of ploughing increases the total porosity and decreases the bulk density of the soil as compared to zero or no tillage (EI-Gohary, 1978). Seedbed preparation also affects the root properties of plants like root volume as Sharma et al. (1988) pointed out that increasing tillage intensity increased the root volume that might be due to better aeration in tilled soils. Keeping in view, all these aspects a study was carried out at Adaptive Research Farm Sheikhupura to evaluate different land preparation methods for super basmati rice.

\section{Materials and Methods}

\section{Site Description}

The study was undertaken consecutively for Kharif 2017 and 2018 at ARF, Sheikhupura. The experimental site is located in the Sheikhupura district of Pakistan. This area is renowned for the production of basmati rice and is called rice tract of Pakistan. The climate is moist sub-humid with an annual rain fall of 250-500 $\mathrm{mm}$. This region has ricewheat cropping system as the major cropping system.

\section{Crop Husbandry}

Each year rice nursery (super basmati) was raised in $2^{\text {nd }}$ week of June and at the age of 30 days was transplanted manually at experimental site. Fertilizers were applied to crop as recommended by Department of Agriculture, Government of Punjab with $140-80-62 \mathrm{~kg} \mathrm{ha}^{-1}$ as N-P-K. Whole $\mathrm{P}$ and $\mathrm{K}$ were applied at the time of transplanting of nursery, while $\mathrm{N}$ was applied in 3 equal splits at tillering, panicle initiation and flowering stage. The sources of $\mathrm{N}, \mathrm{P}$ and $\mathrm{K}$ were urea, di-ammonium phosphate (DAP) and sulphate of potash (SOP), respectively. All the experimental units were also fertilized with zinc sulphate $33 \%$ @ $\mathrm{kg} \mathrm{ha}^{-}$ ${ }^{1}$ to fulfil the $\mathrm{Zn}$ requirements of the crop at tillering stage. All other operations like weed management, irrigation scheduling and management of pests etc. were kept uniform in all experimental units. Each year, the crop was harvested and threshed manually from each plot at maturity.

\section{Experimental Design and Treatments}

Experiment was laid out in randomized complete block design (RCBD) with 4 different land preparation techniques as the treatments and was replicated thrice. The following treatments were applied:

$$
\begin{aligned}
& \mathrm{T}_{1}=\text { Cultivator } 4 \text { times }+ \text { Planking } 2 \text { times (Farmer's Practice) } \\
& \mathrm{T}_{2}=\mathrm{MB} \text { plough } 1 \text { time }+ \text { Disc Harrow } 1 \text { time }+ \text { Planking } 2 \text { Times } \\
& \mathrm{T}_{3}=\mathrm{MB} \text { plough } 1 \text { time }+ \text { Cultivator } 2 \text { times }+ \text { Planking } 2 \text { Times }
\end{aligned}
$$

$\mathrm{T}_{4}=$ Rotavator 1 time + Disc Harrow 1 time + Planking 2 Times
The net plot size was $12 \mathrm{~m} \times 44 \mathrm{~m}$ for each experimental unit during both years.

\section{Data Collection and Statistical Analysis}

Data regarding, plant height at maturity, number of fertile tillers, number of grains per spike, 1000-grain weight and paddy yield was collected using the standard procedures. The collected data were analysed statistically by employing the Fisher's analysis of variance technique. The significance of treatment means was tested using least significance difference (LSD) test at 5\% probability level (Steel et al. 1997).

\section{Results and Discussion}

\section{Plant Height (cm)}

Plant height of rice was significantly affected by different land preparation techniques (Table-1). Data presented in table 1 shows that land preparation technique $\mathrm{T}_{2}$ (MB Plough (1 time) + Disc Harrow (1 time) + Planking (2 times) gave the maximum plant height during both the years i.e., $2017(134 \mathrm{~cm})$ and $2018(132 \mathrm{~cm})$ as compared to other land preparation techniques. The plant height (131.00 and $129.33 \mathrm{~cm}$ during 2017 and 2018, respectively) in treatment $\mathrm{T}_{3}$ (MB plough 1 time + Cultivator 2 times + Planking 2 Times) was also statistically at par with that of plant height in $\mathrm{T}_{2}$ (Table-1). Traditional land preparation technique $\mathrm{T}_{1}$ comprising only cultivator (4 times) + Planking (2 times) had the lowest plant height (121 and $122.33 \mathrm{~cm}$ for 2017 and 2018, respectively) among all the applied treatments during both years (Table-1).

\section{Number of Productive Tillers $\left(\mathrm{m}^{2}\right)$}

Productive tillers are the most important yield contributing parameter in rice crop. Data presented in table2 reveals that for both the years i.e., 2017 and 2018, land prepared by using $\mathrm{T}_{2}$ i.e., MB Plough ( 1 time) + Disc Harrow (1 time) and Planking ( 2 times) gave the highest number of productive tillers i.e., 224 and 220 for 2017 and 2018, respectively. The number of productive tillers (220 and 213 $\mathrm{m}^{-2}$ for 2017 and 2018, respectively) with the use of $\mathrm{T}_{3}$ (MB plough 1 time + Cultivator 2 times + Planking 2 Times) was also statistically similar to $T_{2}$. However, land prepared by using MB Plough (2 times) + cultivator (2 times) + Planking ( 2 times) also gave the similar result for 2017 only as 220 tillers per $\mathrm{m}^{2}$ were recorded in this treatment for 2017 . Lowest number of productive tillers (207 and $202 \mathrm{~m}^{-2}$ for 2017 and 2018 respectively) were observed in $\mathrm{T}_{1}$ where cultivator (4 times) and planking ( 2 times) were used for both the years (Table-2).

\section{Number of Grains Per Spike}

Different land preparation techniques significantly affected the number of grains per spike during both the years. Results given in Table-3 depict that maximum number of grains per spike (130 and 116 grain per spike for 2017 and 2018, respectively) were observed in case of $T_{2}$ where MB Plough (1 time) + Disc Harrow (1 time) + Planking (2 times) was used for both years. Moreover, in $\mathrm{T}_{3}$ i.e., MB Plough (1 time) + Disc Harrow (1 time) + Planking (2 times), the number of grains per spike (127 and 112 for 2017 and 2018, respectively) were also statistically similar to $\mathrm{T}_{2}$. Minimum number of grains per spike (121 and 103 for 2017 and 2018 respectively) were recorded in traditional land preparation technique where only cultivator (4 times) + planking (2 times) was used during both years (Table-3). 
Table 1. Effect of different land preparation techniques on plant height $(\mathrm{cm})$ under Agro-ecological conditions of Sheikhupura-Pakistan during Kharif 2017 and 2018

\begin{tabular}{l|cc}
\hline \multicolumn{1}{c|}{ Treatments } & 2017 & 2018 \\
\hline Cultivator (4 times) + Planking (2 times) (Farmer's Practice) & $121.00^{\mathrm{b}}$ & $122.33^{\mathrm{c}}$ \\
MB plough (1 time) + Disc Harrow (1 time) + Planking (2 Times) & $134.00^{\mathrm{a}}$ & $132.00^{\mathrm{a}}$ \\
MB plough (1 time) + Cultivator (2 times) + Planking (2 Times) & $131.00^{\mathrm{a}}$ & $129.33^{\mathrm{ab}}$ \\
Rotavator (1 time) + Disc Harrow (1 time) + Planking (2 Times) & $128.00^{\mathrm{ab}}$ & $125.00^{\mathrm{bc}}$ \\
LSD (P $\leq 0.05)$ & 7.18 & 4.76 \\
\hline
\end{tabular}

Table 2. Effect of different land preparation techniques on number of productive tillers $\left(\mathrm{m}^{2}\right)$ under Agro-ecological conditions of Sheikhupura-Pakistan during Kharif 2017 and 2018

\begin{tabular}{l|cc}
\hline \multicolumn{1}{c|}{ Treatments } & 2017 & 2018 \\
\hline Cultivator (4 times) + Planking (2 times) (Farmer's Practice) & $207.0^{\mathrm{c}}$ & $202.0^{\mathrm{c}}$ \\
MB plough (1 time) + Disc Harrow (1 time) + Planking (2 Times) & $224.0^{\mathrm{a}}$ & $220.0^{\mathrm{a}}$ \\
MB plough (1 time) + Cultivator (2 times) + Planking (2 Times) & $220.0^{\mathrm{a}}$ & $213.0^{\mathrm{ab}}$ \\
Rotavator (1 time) + Disc Harrow (1 time) + Planking (2 Times) & $214.0^{\mathrm{b}}$ & $209.0^{\mathrm{bc}}$ \\
LSD (P $\leq 0.05)$ & 5.50 & 8.72 \\
\hline
\end{tabular}

Table3. Effect of different land preparation techniques on number of grains per spike under Agro-ecological conditions of Sheikhupura-Pakistan during Kharif 2017 and 2018

\begin{tabular}{l|cc}
\hline \multicolumn{1}{c|}{ Treatments } & 2017 & 2018 \\
\hline Cultivator (4 times) + Planking (2 times) (Farmer's Practice) & $121.0^{\mathrm{c}}$ & $103.0^{\mathrm{c}}$ \\
MB plough (1 time) + Disc Harrow (1 time) + Planking (2 Times) & $130.0^{\mathrm{a}}$ & $116.0^{\mathrm{a}}$ \\
MB plough (1 time) + Cultivator (2 times) + Planking (2 Times) & $127.0^{\mathrm{ab}}$ & $112.0^{\mathrm{ab}}$ \\
Rotavator (1 time) + Disc Harrow (1 time) + Planking (2 Times) & $123.0^{\mathrm{bc}}$ & $109.0^{\mathrm{b}}$ \\
LSD (P $\leq 0.05)$ & 5.62 & 5.40 \\
\hline
\end{tabular}

Table 4. Effect of different land preparation techniques on 1000-grain weight (g) under Agro-ecological conditions of Sheikhupura-Pakistan during Kharif 2017 and 2018

\begin{tabular}{l|cc}
\hline \multicolumn{1}{c|}{ Treatments } & 2017 & 2018 \\
\hline Cultivator (4 times) + Planking (2 times) (Farmer's Practice) & $19.5^{\mathrm{c}}$ & $19.0^{\mathrm{b}}$ \\
MB plough (1 time) + Disc Harrow (1 time) + Planking (2 Times) & $23.0^{\mathrm{a}}$ & $22.0^{\mathrm{a}}$ \\
MB plough (1 time) + Cultivator (2 times) + Planking (2 Times) & $22.0^{\mathrm{ab}}$ & $21.5^{\mathrm{ab}}$ \\
Rotavator (1 time) + Disc Harrow (1 time) + Planking (2 Times) & $21.5^{\mathrm{b}}$ & $20.0^{\mathrm{ab}}$ \\
LSD (P $\leq 0.05)$ & 1.29 & 2.59 \\
\hline
\end{tabular}

Table 5. Effect of different land preparation techniques on paddy yield ( $\left.\mathrm{kg} \mathrm{ha}^{-1}\right)$ under Agro-ecological conditions of Sheikhupura-Pakistan during Kharif 2017 and 2018

\begin{tabular}{l|cc}
\hline \multicolumn{1}{c|}{ Treatments } & 2017 & 2018 \\
\hline Cultivator (4 times) + Planking (2 times) (Farmer's Practice) & $3700 \mathrm{c}$ & $3360 \mathrm{~d}$ \\
MB plough (1 time) + Disc Harrow (1 time) + Planking (2 Times) & $4200 \mathrm{a}$ & $3950 \mathrm{a}$ \\
MB plough (1 time) + Cultivator (2 times) + Planking (2 Times) & $4000 \mathrm{~b}$ & $3850 \mathrm{~b}$ \\
Rotavator (1 time) + Disc Harrow (1 time) + Planking (2 Times) & $3750 \mathrm{c}$ & $3650 \mathrm{c}$ \\
LSD (P $\leq 0.05)$ & 99.89 & 66.01 \\
\hline
\end{tabular}

Table 6. Cost benefit analysis for paddy production using different land preparation techniques under Agro-ecological conditions of Sheikhupura-Pakistan during Kharif 2017 and 2018

\begin{tabular}{l|cc}
\hline \multicolumn{1}{c|}{ Treatments } & 2017 & 2018 \\
\hline Cultivator (4 times) + Planking (2 times) (Farmer's Practice) & 0.17 & 0.15 \\
MB plough (1 time) + Disc Harrow (1 time) + Planking (2 Times) & 0.19 & 0.18 \\
MB plough (1 time) + Cultivator (2 times) + Planking (2 Times) & 0.18 & 0.17 \\
Rotavator (1 time) + Disc Harrow (1 time) + Planking (2 Times) & 0.17 & 0.16 \\
\hline
\end{tabular}

\section{0-Grain Weight (g)}

Grain weight index was also significantly affected by all the land preparation techniques as presented in Table-4. The highest 1000-grain weight $23 \mathrm{~g}$ (2017) and $22.0 \mathrm{~g}$ (2018) was recorded with the use of $\mathrm{T}_{2}$ having MB Plough (1 time) + Disc Harrow (1 time) + Planking (2 times). In treatment $\mathrm{T}_{3}$ having $\mathrm{MB}$ plough (1 time) + Cultivator (2 times) + Planking (2 Times) were also recorded the statistically similar results during Kharif-2017. $\mathrm{T}_{1}$ (Cultivator (4 times) + Planking ( 2 times) for both years 2017 and 2018 showed the lowest 1000 grain weight. The minimum 1000-grain weight i.e., $21.5 \mathrm{~g}$ and $20.0 \mathrm{~g}$ respectively for 2017 and 2018 was recorded when cultivator (4 times) + planking (2 times) was used for land preparation (Table-4). 


\section{Paddy Yield (kg ha-1)}

A significant effect of different land preparation techniques was observed on paddy yield during year 2018 by the application of different land preparation techniques as presented in Table-5. Highest paddy yields $4200 \mathrm{~kg} \mathrm{ha}^{-}$ ${ }^{1}$ and $3950 \mathrm{~kg} \mathrm{ha}^{-1}$ for the year 2017 and 2018 , respectively was recorded in $\mathrm{T}_{2}$ when $\mathrm{MB}$ Plough (1 time) + Disc Harrow (1 time) + Planking (2 times) was used for the land preparation. Moreover, statistically similar results were recorded from Cultivator (4 times) + Planking (2 times) and Rotavator (1 time) + Disc Harrow (1 time) + Planking (2 Times) only for the year 2017. Minimum paddy yields $3700 \mathrm{~kg} \mathrm{ha}^{-1}$ and $3360 \mathrm{~kg} \mathrm{ha}^{-1}$ for the year 2017 and 2018 respectively was recorded in case of Cultivator (4 times + Planking (2 times) at Adaptive Research Farm, Shiekhupura (Table 5).

\section{Cost Benefit Analysis}

The final paddy yield achieved in each treatment was divided by the cost incurred in that treatment to find the cost benefit ratio as presented in table- 6 . The values are describing the paddy yield in $\mathrm{kg}$ achieved with each PKR (Pak-Rupee) incurred on producing the paddy. It showed that the highest return ( 0.19 and $0.18 \mathrm{~kg}$ per PKR for 2017 and 2018) was gained with the application of treatment $T_{2}$ i.e., MB plough (1 time) + Disc Harrow (1 time) + Planking (2 Times). The net return in case of $\mathrm{T}_{3}$ was also more or less equal to that of $T_{2}$, however in case of $T_{1}$ and $T_{4}$, the net return was much lesser as compared to that of $\mathrm{T}_{2}$ and $\mathrm{T} 3$.

It is well reported in literature that different tillage practices alter soil physical, chemical and biological properties that ultimately affect the final crop yield (Çarman, 1997; Ozpinar and Clay, 2006; Rashidi and Keshavarzpour, 2007). In case of rice, soil tillage is generally associated with puddling intensity and puddling intensity has significant effect on soil bulk density (Sharma et al., 2005), its structure and hydraulic conductivity (Kakul and Aggarwal, 2002) and penetration resistance (Mohanty et al.,2004).Results given in table 1-5 show that different land preparation techniques had significantly affected the yield of paddy and all other yield contributing parameters like number of tillers, number of grains per spike and 1000 grain weight. It might be due to change in soil structure and different soil physical properties including bulk density, porosity water holding capacity etc. Shad and De Datta (1986) showed that among zero, minimum and conventional tillage, the last one i.e., conventional tillage is best for growing rice as it gave highest paddy yield. It is also reported that increasing the tillage intensity in clay soils increase the root volume of rice plant that causes better aeration and more nutrient uptake which might be the best possible explanation for higher paddy yield under deep tillage systems than in zero and minimum tillage (Sharma et al., 1988). Different tillage techniques impose significant effect on puddling index, infiltration rate and grain yield of rice crop (Tripathi et al., 2007). Deep tillage or intensive tillage decrease hydraulic conductivity of soil that in turn decreases evaporation from the surface of soil limiting the evaporation losses from the soil surface (Ringrose-Voase et al., 2002). In the present study, highest yield in one double puddling might be due to optimum puddling density that optimized the evaporation from soil surface, increased soil aeration and did not affect the penetration resistance to risky extents whereas in case of dry land preparation and of two double puddles all these soil properties were modified in such a way that did not favour the plant growth ultimately leading to lower paddy yields. The highest yield and all other associated parameters in case of $\mathrm{T} 2$ could be considered as the result of use of disc harrow for land preparation. It is well documented in literature that the use of disk harrow increases soil pulverization than that of moldboard plough (Nassir et al, 2016; Aday et al, 2001). In this study, the use of disk harrow might had increased the soil pulverization leading toward more root penetration in the soil to extract mote nutrient ultimately increasing the crop yield. The use of MB plough had also done the same but the level of pulverization was less than that of disk harrow, so a little lower yield was recorded in case of use of MB plough.

\section{Conclusion}

The present study suggests that under agro-ecological conditions of Sheikhupura-Pakistan, $\mathrm{T}_{2}$ (MB plough 1 time + Disc Harrow 1 time + Planking 2 Times) is the best land preparation method for optimum paddy yields, so it should be adapted by farmers of this region.

\section{References}

Aday SH, Hamid KA, Salman RF. 2001. The energy requirement and energy utilization efficiency of two plows type for pulverization of heavy soil. Iraqi Journal of Agriculture, 6(1): 137-146.

Carman K. 1997. Effect of different tillage systems on soil properties and wheat yield in Middle Anatolia, Soil and Tillage Research, 40(3-4): 201-207.

Chang C, Lindwall CW. 1990. Comparison of the Effect of LongTerm Tillage and Crop Rotation on Physical Properties of a Soil. Canadian Agri. Engineering, 32: 53-55.

Culpin C. 1981. Farm Machinery, Granada Publishing Limited, Great Britain, p.52. ISBN:9780246115850

El- Gohary EAA. 1978. Study of some soil physical properties effect of ploughing depth on some soil physical properties, cotton growth and yield in clay soil. M.Sc. Thesis, Faculty of Agriculture, Tanta University, Egypt.

Khairul Alam Md, Monirul Islam Md, Salahin Nazmus, Hasanuzzaman Mirza 2014. Effect of Tillage Practices on Soil Properties and Crop Productivity in Wheat-MungbeanRice Cropping System under Subtropical Climate Conditions. The Scientific World Journal 2014: 1-15.

Kukal SS, Aggarwal GC. 2002. Percolation losses of water in relation to puddling intensity and depth in a sandy loam rice (Oryzasativa) field. Agricultural Water Management 57: 49-59.

Mohanty M, Painuli DK, Mandal KG. 2004. Effect of pudlling intensity on temporal variation in soil physical condition and yield of rice (Oryzasativa L.) in a Vertisol of central India. Soil and Tillage Research. 76: 83-94.

Nasiri M, Nicknejad Y, Pirdeshti H, Tari DB, Nasiri S. 2008. Growth, yield and yield traits of rice varieties in rotation with clover, Potato, Canola and cabbage in North of Iran. Asian Journal of Plant Sciences 7(5): 495-499.

Nassir A, 2017. The effect of tillage methods on energy pulverization requirements under various operating conditions in silty loamy soil. Thi-Qar J. Agric. Res., 6(2): 248-257

Ozpinar S, Clay A. 2006. Effect of different tillage systems on the quality and crop productivity of a clay-loam soil in semi-arid north western Turkey, Soil and Tillage Research, 88(1-2): 95106. 
Hobbs PR. 2001.Tillage and Crop Establishment in South Asian Rice - Wheat Systems.Journal of Crop Production. 4(1): 122.

Tripathi RP, Sharma P, Singh S. 2007. Influence of tillage and crop residue on soil physical properties and yields of rice and wheat under shallow water table conditions. Soil and Tillage Research.92: 221-226

Rashidi M, Keshavarzpour F. 2007. Effect of Different Tillage Methods on Grain Yield and Yield Components of Maize (Zea mays L.), International Journal of Agriculture and Biology. 9(2): 274-277.

Rehman A, Jingdong L, Shahzad B, Chandio AA, Hussain I, Nabi G, Iqbal MS, 2015. Economic perspectives of major field crops of Pakistan: An empirical study. Journal of Pacific Science Review B: Humanities and Social Sciences 1(3): 145-158. http://dx.doi.org/10.1016/j.psrb.2016.09.002.

Ringrose-Voase AJ, Kirby JM, Gunomo Djoyowasito WB, Sanidad C, Lando M. 2002. Changes to the physical properties of soils puddled for rice during drying. Soil and Tillage Research, 56: 83-104.
Shad AR, De Datta SK. 1986. Reduced tillage techniques for wetland rice as affected by herbicides. Soil and Tillage Research. 6:291-303.

Shahidur Rahman Md, Asraful Haque Md, Abdus Salam Md. 2004. Effect of Different Tillage Practices on Growth, Yield and Yield Contributing Characters of Transplant Amon Rice (BRRI Dhan-33). Journal of Agronomy, 3: 103-110.

Sharma P, Tripathi RP, Singh S. 2005. Tillage effects on soil physical properties and performance of rice-wheatcropping system under shallow water table table conditions of Tari, Northern India. European Journal of Agronomy. 23: 327-335.

Sharma PK, De Datta SK, Redulla CA. 1988. Tillage effects on soil physical properties and wetland rice yield. AgronomyJournal.80: 34-39.

Steel RGD, Torrie JH, Dickey D. 1997.Principles and Procedure of Statistics. A Biometrical Approach 3rd Ed. McGraw Hill Book Co. Inc., New York. pp. 352-358. ISBN:97800 70609259 